Keywords:

Labile fraction

Humic substances

Geostatistics

Soil quality indicators

Histórico:

Recebido 28/02/2017

Aceito 27/05/2017

Palavras chave:

Fração lábil

Substâncias húmicas

Geoestatística

Indicadores de qualidade do solo

${ }^{+}$Correspondência: mgervasiopereira0I@gmail.com
Camila Santos da Silva', Marcos Gervasio Pereira ${ }^{{ }^{+}}$, Rafael Coll Delgado', Shirlei Almeida Assunção'

\section{SPATIALIZATION OF FRACTIONS OF ORGANIC MATTER IN SOIL IN AN AGROFORESTRY SYSTEM IN THE ATLANTIC FOREST, BRAZIL}

ABSTRACT: This study aimed to spatialize fractions of organic matter of soil in an agroforestry system (AFS) located in the Atlantic Forest in Brazil. Thirty-one soil samples were collected at depths of $0-10,10-20$ and $20-40 \mathrm{~cm}$ from georeferenced collection points. We determined total organic carbon (TOC), particulate carbon (COp), carbon associated with clay and silt (COam), carbon content in the fulvic acid fraction (C-FAF), humic acid fraction (C-HAF) and humin fraction (C-HUM). Semivariogram analysis and model adjustment were carried out using ArcGIS 10.2 software. Subsequently, spatial interpolation was performed using Ordinary Kriging. We observed spatial dependence for all variables except for TOC and COp at the $0-10 \mathrm{~cm}$ depth, which presented a pure nugget effect. It was possible to observe modifications in the distribution of humic substances in the study area. The results from this study are similar to those of other studies conducted in naive areas in the Atlantic Forest, demonstrating the benefits of using the agroforestry system.

\section{ESPACIALIZAÇÃO DAS FRAÇÕES DA MATÉRIA ORGÂNICA DO SOLO SOB UM SISTEMA AGROFLORESTAL, NA MATA ATLÂNTICA, BRASIL}

RESUMO: Este estudo teve como objetivo espacializar as frações da matéria orgânica do solo em um sistema agroflorestal (SAF) localizado na Mata Atlântica. Foram coletadas trinta e uma amostras de terra nas profundidades de 0-10, 10-20 e 20-40 cm, sendo cada ponto georeferenciado. Foram determinados os teores de carbono orgânico total (COT), carbono particulado (COP), carbono associado a argila e silte (COam), teor de carbono na fração de ácido fúlvico (C-FAF), fração de ácido húmico (C-FAH) e fração de humina (C-HUM). A análise dos semivariogramas e o ajuste do modelo foram realizados utilizando o software ArcGIS 10.2. Posteriormente foi realizada a interpolação espacial através de Krigagem Ordinária. Foi observada dependência espacial para todas as variáveis, com exceção do COT e COp na profundidade de $0-10 \mathrm{~cm}$, visto que apresentaram efeito pepita puro. Foram verificadas modificações na distribuição das substâncias húmicas na área de estudo. Os resultados deste estudo são semelhantes aos de outros realizados em áreas de Mata Atlântica, demonstrando os benefícios do uso do sistema agroflorestal. 


\section{INTRODUCTION}

The Atlantic Forest is one of the most important biomes in Brazil owing to its diversity of fauna and flora, traditional populations, valuable cultural heritage. Protecting soil and water bodies is important in this region (MMA, 1998). Over recent decades, the Atlantic Forest has gone through a period of exploitation of agricultural products for export, leading to its deforestation (MEISTER; SALVIATI, 2009). Current techniques can reverse or reduce the negative impacts of deforestation, reconciling food production with increasing biodiversity and protecting soil against degradation (FROUFE; SEOANE, 20II). The agroforestry system (AFS) is a form of land management, in which trees, agricultural crops and / or animals are intercropped, being deployed simultaneously or sequentially (MAGALHÃES et al., 20I3). This system is a form of soil use that combines agricultural production and the conservation of natural resources (JOSE, 2009), providing environmental services such as soil conservation, carbon sequestration, biodiversity preservation, and an increase in water quality (NAIR, 20II). It also acts in the recovery of degraded areas, helping to reestablish soil properties (PEZARICO et al., 2013). Whereas monoculture and conventional soil preparation have been causing a decrease in natural resources and degradation of the physical, chemical and biological properties of soil (MACEDO, 2009).

The physical, chemical and biological properties of soil have been used as quality indicators to evaluate environmental sustainability (DORAN; PARKIN, 1994; CHAER; TÓTOLA, 2007; MAIA, 2013). Among them, soil organic matter (SOM) is one of the key indicators of sustainability and environmental quality in agroecosystems (ROSSI et al., 20II), and can be analyzed by chemical or physical fractionation. One of the techniques for studying stratification of organic carbon content in the soil is the chemical fractionation of organic matter. This technique is used to evaluate carbon content in the different humic fractions of the soil, which can be divided into humin, humic acids, and fulvic acids (SANTOS et al., 2013). Through granulometric fractionation of organic matter, changes resulting from the use or management of areas can be identified. Two fractions are obtained from this technic: particulate organic carbon (COp) and organic carbon associated with minerals (COam) (GAZOLLA et al., 20I5).

Few studies have investigated the spatial distribution of SOM fractions (MARCHETTI et al., 20I2) as indicators of the quality of the site, especially in agroforestry systems. Geostatistics has been used in soil science to characterize and analyze the spatial variation of soil attributes (ZONTA et al., 20I4), and in this case to understand the spatial variability of SOM and its fractions. This tool allows the estimation of variables in non-sampled from nearby sampled points. Therefore, this study aimed to apply spatial analysis in fractions of soil organic matter from an agroforestry system, located in the Atlantic Forest.

\section{MATERIAL AND METHODS}

The study was carried out in an agroforestry system of approximately $3,397 \mathrm{~m}^{2}$, Latitude $23^{\circ} \mathrm{S}$ and Longitude $44^{\circ} \mathrm{W}$, located in the Integrated Agroecological Production System, on the Embrapa Agrobiology grounds in Seropédica, Rio de Janeiro, Brazil. The regional climate is 'Aw', according to Köppen classification, with rainfall concentrated between November and March, an annual average precipitation of $\mathrm{I}, 2 \mathrm{I} 3 \mathrm{~mm}$, and an annual average air temperature of $23.9^{\circ} \mathrm{C}$. The maximum and minimum altitude of the AFS is $41.0 \mathrm{~m}$ and $26.3 \mathrm{~m}$, respectively. The predominant land relief is low and undulating with $<5 \%$ slope. The soil is classified as Planossolo Háplico (Fragiudult) (SANTOS et al., 2013).

Prior to implementation of the AFS, banana (Musa sapientum L.) and papaya (Carica papaya L.) were grown in the area and fertilized with cattle manure. Around the year 2000, the AFS was implemented with a multilayered arrangement, in which it is characterized by the high presence of different species and by the occupation of the vertical and horizontal space of the different strata (FROUFE et al., 20II). Crop trees such as açaí palm (Euterpe oleracea Mart.), cupuaçu (Theobroma grandiflorum (Willd. ex Spreng.) K.Schum.), Brazilian cherry (Eugenia brasiliensis Lam.), citrus (Citrus sp.) and guapuruvu (Schizolobium parahyba (Vell.) Blake) were planted along with cabbage (Brassica oleracea L.) and forage peanuts (Arachis pintoi Krapov. \& W.C. Gregory), the latter for green manure. Some tree species that previously existed on the site were used, such as royal poinciana (Delonix regia (Boj. ex. Hook.) Rafin.), for landscape aesthetic purposes. New species were planted from 2002 to 2008, such as gliricidia (Gliricidia sepium (Jacq.) Walp.), jackfruit (Artocarpus heterophyllus Lam.), carrapeta (Guarea guidonia (L.) Sleumer), tucandeiro (Citharexylum myrianthum Cham.) and several species of the family Arecaceae. The most intense management was carried out in the first two years, with the aforementioned plantings associated with pruning, mowing, manuring, harvesting, and weeding. There are no reports of management practices in the area after the first eight years. 
The study area was divided into a $10 \times 10$ m grid cell in which $3 \mathrm{I}$ sampling units were selected in order to have the highest representativity of the points collected for spatial interpolation. Soil samples were collected from the center of each plot, under the shade of the species in the area, at depths of $0-10 \mathrm{~cm}, 10-20 \mathrm{~cm}$, and $20-40 \mathrm{~cm}$ using a probe. After the collection of soil samples, each point was georeferenced with a Promark 2 Geodetic GPS device. Soil samples were taken to the laboratory, dried in shade, then crushed and filtered with a 2-mm sieve to obtain air-dried fine earth (ADFE) for use in the following analyses.

Total organic carbon (TOC) was determined according to Yeomans and Bremner (1988). Physical fractionation of organic matter (OM) was performed according to the method of Cambardella and Elliot (I992).

For this, $10 \mathrm{~g}$ of air-dried fine earth were weighed and $30 \mathrm{~mL}$ of sodium hexametaphosphate solution (5 $\left.g^{-1}\right)$ were added, the samples were homogenized for 16 hours on a horizontal shaker. After homogenization, the obtained suspension was passed through a $53 \mu \mathrm{m}$ sieve. The material retained in the sieve corresponds to COp (particulate organic carbon) associated to the sand fraction, and the permeate to the sieve corresponds to the silt and clay fractions.

The material retained in the sieve, after washing, was deposited in glass, and dried in a forced circulation oven at $65^{\circ} \mathrm{C}$ until it had a constant mass. Subsequently, the material was macerated in porcelain grains and analyzed for organic carbon content according to Yeomans and Bremner (1988). The content of organic carbon associated with minerals (COam) was defined by the difference between the TOC content and the COp content.

For chemical fractionation of SOM, we used the differential solubility technique (SWIFT, 1996) with adaptations by Benites et al. (2003), to obtain the organic carbon in fulvic acid fraction (C-FAF), humic acid fraction (C-HAF) and humin fraction (C-HUM). This analysis was carried out only for samples at $0-10 \mathrm{~cm}$ depth, which is the layer with highest carbon content.

For this, a soil mass (TFSA) having $30 \mathrm{mg}$ of organic carbon was weighed by adding $20 \mathrm{~mL}$ of 0.1 $\mathrm{mol} \cdot \mathrm{L}^{-1} \mathrm{NaOH}$ per 24 hours, alkaline extract $(\mathrm{AE})$, to the contact. The separation between the alkaline extract $(A E=F A F+H A F)$ and the residue was done by centrifugation at $5000 \mathrm{~g}$ for 30 minutes. Further, washing with the same solution was continued, adding the extract with the previously obtained, resulting in a final volume of approximately $40 \mathrm{~mL}$. The residue was stored for humin determination $(\mathrm{C}-\mathrm{HU})$. The $\mathrm{pH}$ of $\mathrm{AE}$ was adjusted to
I. 0 with $20 \% \mathrm{H}_{2} \mathrm{SO}_{4}$, followed by decantation for 18 hours. The precipitate (C-HAF) was separated from the soluble fraction (C-FAF) by filtration and both volumes were adjusted to $50 \mathrm{~mL}$ with distilled water.

The quantitative determination of the organic carbon in C-FAF and C-HAF was carried out using 5.0 $\mathrm{mL}$ of extract, $1.0 \mathrm{~mL}$ of potassium dichromate 0.042 $\mathrm{mol} \cdot \mathrm{L}^{-1}$ and $5.0 \mathrm{~mL}$ of concentrated $\mathrm{H}_{2} \mathrm{SO}_{4}, 150^{\circ} \mathrm{C}(30$ minutes) and titration with ammonia ferrous sulfate $0.0125 \mathrm{~mol} \cdot \mathrm{L}^{-1}$. In the residue, the organic carbon of the humin fraction (C-HU) was determined, after drying the oven material at $65^{\circ} \mathrm{C}$ (complete drying), $5.0 \mathrm{~mL}$ of $0.1667 \mathrm{~mol} \cdot \mathrm{L}^{-1}$ potassium dichromate and $10.0 \mathrm{~mL}$ of concentrated $\mathrm{H}_{2} \mathrm{SO}_{4}$, in a $150^{\circ} \mathrm{C}$ (30 minutes) digester block and titration with $0.25 \mathrm{~mol} \cdot \mathrm{L}^{-1}$ ammoniacal ferrous sulfate (YOEMANS; BREMNER, 1988).

Data obtained in the analyses of chemical and physical fractionation of the SOM were entered into Microsoft Excel (2013) spreadsheets and associated with sample geographic coordinates to enable data spatialization.

For each variable, descriptive statistics were produced using statistical software R 3.2.5. Outlier data were identified and eliminated according to box plots. To test the hypothesis of data normality, the ShapiroWilk test was performed at $5 \%$ probability. Variables were transformed into logarithmic scale when necessary. Verification of spatial dependence by the semivariogram calculation was performed, in which the exponential, spherical, and Gaussian theoretical models were adjusted and tested in order to verify which model best represented the distribution of the variables studied, based on the equations and the three physical models presented by Silva et al. (2016). To validate and verify the performance of the models in the estimation of the variables, the following parameters were used: lowest degree of spatial dependence (DSD \%), highest correlation coefficient $(R)$, highest coefficient of determination $\left(R^{2}\right)$, highest Willmott's concordance index (d), lowest standard error of the estimate (SEE), and lowest root-mean-squareerror (RMSE) (WILLMOTT, 1982; CAMBARDELLA et al., 1994; SILVA et al., 2016). DSD can be classified as follows, with values $\leq 25 \%$ suggesting data with strong spatial dependence, values between $25 \%$ and $75 \%$, suggesting moderate spatial dependence, and values $\geq$ $75 \%$ suggesting weak spatial dependence. For a DSD equal to $100 \%$, the variable is spatially independent; that is, the semivariogram shows a pure nugget effect (PNE).

After the spatial dependence was verified, ordinary kriging was applied to estimate variables in nonsampled places, making it possible to produce maps. 
Semivariogram analysis and kriging were carried out using ArcGIS 10.2 software.

\section{RESULTS AND DISCUSSION}

Certain variables did not present a normal distribution (Table I). However, according to Isaaks and Srivastava (1989), it is more important that data are spatially dependent rather than normally distributed, especially when data are obtained in nature, in which normal distribution is only approximate (WARRICK; NIELSEN, 1980).

Coefficients of skewness and kurtosis were low for the variables that presented normal distribution and high for the variables that presented non-normal distribution. These results can be confirmed by mean and median values: when these measures have values that distant from each other, they show asymmetric distributions, with values of skewness distant from zero (SOUZA et al., 2004).

The CV values of nearly all variables were considered average, with the exception of C-HAF, which showed high variability of the data at $66.42 \%$. According to Warrick and Nielsen (1980), CV values between 12 and $60 \%$ have an average variability and values below and above this range indicate low and high variability of data, respectively. Prior to semivariance calculation and to improve the spatial dependence of data, a logarithmic transformation was carried out for the variable COp ( I0$20 \mathrm{~cm}$ ) and discrepant values were removed as outliers for the variables C-HAF, C-HUM, TOC (10-20 and 20$40 \mathrm{~cm})$, and COam $(20-40 \mathrm{~cm})$.

There was spatial dependence for all variables, except for TOC and COp at the depth of $0-10 \mathrm{~cm}$, as they showed pure nugget effect (Table 2). Therefore, to estimate these variables in the AFS, it is possible to sample more points and/or reduce the space between them, or even apply non-stochastic methods, such as the inverse square-distance (ISD) method used when there is no spatial correlation (YAMAMOTO; LANDIM, 20I3).

The model that best fit the dataset was exponential, followed by spherical and Gaussian models. The variables C-FAF, C-HUM, COp and COam at 20-40 cm depth presented strong spatial dependence, while the variables C-HAF, TOC, COp and COam (I0-20 cm) and TOC (20$40 \mathrm{~cm}$ ) showed moderate spatial correlation and the COam variable $(0-10 \mathrm{~cm})$ presented weak spatial dependence.

Leite et al. (2015) conducted a study evaluating the spatial variability of SOM fractions in a degraded area under recovery with Jatropha curcas L., in southwestern Piauí, and found different results of the present study. They adjusted the spherical model for the TOC and labile carbon (LC) variables in the $0-5 \mathrm{~cm}$ layer, for TOC, $\mathrm{C}-\mathrm{HAF}$ and $\mathrm{C}-\mathrm{HUM}$ variables in the $5-10 \mathrm{~cm}$ layer and for TOC in the 10-20 cm layer. The exponential model was adjusted for the variables C-HAF $(0-5 \mathrm{~cm})$, LC (5$10 \mathrm{~cm})$ and LC (10-20 cm). The Gaussian model was adjusted for the variables C-FAF in the $5-10 \mathrm{~cm}$ layer, and C-FAF, C-HAF and C-HUM in the $10-20 \mathrm{~cm}$ layer.

The highest correlation coefficient (R) and determination $\left(R^{2}\right)$ were 0.77 and 0.60 , respectively, for the variable $C-F A F$, and the lowest $R$ and $R^{2}$ were -0.18 and 0.03 for the TOC $0-10 \mathrm{~cm}$ variable. The models adjusted for soil organic matter fractions presented concordance index (d) varying from 0.44 to 0.76 . The RMSE expresses the real value of the error generated by the model, which was higher for the TOC $0-10 \mathrm{~cm}$ variables (which presented EPP), and for COam at 20-40 $\mathrm{cm}$, with a value of $\mathrm{I} .0 \mathrm{I} \mathrm{g} \cdot \mathrm{kg}^{-1}$ for both variables. This was lower for C-FAF at $0.75 \mathrm{~g} \cdot \mathrm{kg}^{-1}$. The SEE for the adjusted models ranged from 0.08 to $1.94 \mathrm{~g} \cdot \mathrm{kg}^{-1}$.

TABLE I Descriptive analysis of TOC, COp, and COam content in the 0-10, 10-20 and 20-40 cm depths, and C-FAF, C-HAF and C-HUM of $0-10 \mathrm{~cm}$ depth of an AFS in the Atlantic Forest.

\begin{tabular}{|c|c|c|c|c|c|c|c|}
\hline Variables & Mean & Median & $\mathrm{SD}^{(7)}$ & $\mathrm{CV}^{(8)}(\%)$ & Skewness & Kurtosis & $W^{(9)}$ \\
\hline \multicolumn{8}{|c|}{$0-10 \mathrm{~cm}$} \\
\hline $\mathrm{TOC}^{(1)}\left(\mathrm{g} \cdot \mathrm{kg}^{-1}\right)$ & 21.28 & 21.21 & 7.11 & 33.43 & -0.19 & -0.34 & $0.98 \mathrm{~ns}$ \\
\hline $\mathrm{COp}^{(2)}\left(\mathrm{g} \cdot \mathrm{kg}^{-1}\right)$ & 5.80 & 5.42 & 1.46 & 25.21 & 0.51 & -0.92 & $0.04 *$ \\
\hline $\mathrm{COam}^{(3)}\left(\mathrm{g} \cdot \mathrm{kg}^{-1}\right)$ & 15.68 & 14.74 & 6.14 & 39.16 & -0.07 & -0.83 & $0.64 n s$ \\
\hline C-FAF ${ }^{(4)}\left(\mathrm{g} \cdot \mathrm{kg}^{-1}\right)$ & 1.48 & 1.16 & 0.87 & 58.57 & 0.32 & -1.35 & $0.02 *$ \\
\hline C-HAF(5) $\left(\mathrm{g}^{\prime} \cdot \mathrm{kg}^{-1}\right)$ & 1.52 & $\mathrm{I} .4 \mathrm{I}$ & I.0I & 66.42 & 0.75 & -0.25 & $0.02 *$ \\
\hline \multirow[t]{2}{*}{$\mathrm{C}-\mathrm{HUM}^{(6)}\left(\mathrm{g} \cdot \mathrm{kg}^{-1}\right)$} & 8.71 & 8.96 & 3.40 & 39.10 & 0.34 & 0.42 & $0.79 \mathrm{~ns}$ \\
\hline & \multicolumn{7}{|c|}{$10-20 \mathrm{~cm}$} \\
\hline TOC $\left(\mathrm{g} \cdot \mathrm{kg}^{-1}\right)$ & 13.62 & 12.42 & 4.19 & 30.73 & 0.79 & 0.23 & $0.10 \mathrm{~ns}$ \\
\hline $\operatorname{COp}\left(\mathrm{g} \cdot \mathrm{kg}^{-1}\right)$ & 4.13 & 3.92 & 0.99 & 24.10 & 0.83 & 0.43 & $0.09 \mathrm{~ns}$ \\
\hline \multirow[t]{2}{*}{ COam $\left(\mathrm{g} \cdot \mathrm{kg}^{-1}\right)$} & 9.49 & 7.95 & 3.62 & 38.13 & 0.69 & -0.59 & $0.02 *$ \\
\hline & \multicolumn{7}{|c|}{$20-40 \mathrm{~cm}$} \\
\hline TOC $\left(\mathrm{g} \cdot \mathrm{kg}^{-1}\right)$ & 9.54 & 9.00 & 2.82 & 29.59 & 1.15 & 2.57 & $0.03 *$ \\
\hline $\operatorname{COp}\left(\mathrm{g} \cdot \mathrm{kg}^{-1}\right)$ & 3.33 & 3.30 & 0.68 & 20.50 & 0.08 & -0.51 & $0.96 \mathrm{~ns}$ \\
\hline COam $\left(\mathrm{g} \cdot \mathrm{kg}^{-1}\right)$ & 6.21 & 5.81 & 2.76 & 44.43 & 1.16 & 2.77 & $0.02 *$ \\
\hline
\end{tabular}

(I)Total organic carbon; (2)Particulate organic carbon; (3)Organic carbon associated with minerals; (4)Organic carbon in fulvic acid fraction; (5)Organic carbon in humic acid fraction (6)Humin fraction; (7)Standard deviation; (8)Coefficient of variation; (9)Shapiro-Wilk test; nsNon-significant; *Significant ( $p$ < 0.05). 
TABLE 2 Parameters estimates of the omnidirectional and cross semivariograms Vol = volume, Exp = Exponential.

\begin{tabular}{|c|c|c|c|c|c|c|c|c|}
\hline Variables & $R^{(7)}$ & $R^{2(8)}$ & $d^{(9)}$ & $\operatorname{SEE}^{(10)}$ & $\operatorname{RMSE}^{(I I)}$ & $\operatorname{DSD}^{(12)}(\%)$ & Class & Model \\
\hline & \multicolumn{8}{|c|}{$0-10 \mathrm{~cm}$} \\
\hline $\operatorname{TOC}^{(I)}\left(\mathrm{g} \cdot \mathrm{kg}^{-1}\right)$ & -0.18 & 0.03 & 0.44 & 1.30 & 1.01 & 100.00 & $\mathrm{PNE}^{(13)}$ & - \\
\hline $\operatorname{COp}^{(2)}\left(\mathrm{g} \cdot \mathrm{kg}^{-1}\right)$ & 0.22 & 0.05 & 0.55 & 0.08 & 0.98 & 100.00 & PNE & - \\
\hline $\mathrm{CO}^{(3)}\left(\mathrm{g}^{\prime} \mathrm{kg}^{-1}\right)$ & 0.18 & 0.03 & 0.54 & 1.94 & 0.96 & 75.07 & Weak & Exponential \\
\hline C-FAF(4) $\left(\mathrm{g} \cdot \mathrm{kg}^{-1}\right)$ & 0.77 & 0.60 & 0.76 & 0.16 & 0.75 & 21.00 & Strong & Exponential \\
\hline C-HAF ${ }^{(5)}\left({\left.\mathrm{g} \cdot \mathrm{kg}^{-1}\right)}^{-1}\right.$ & 0.52 & 0.27 & 0.69 & 0.38 & 0.99 & 31.58 & Moderate & Spherical \\
\hline \multirow[t]{2}{*}{ C-HUM(6) $\left(\mathrm{g}^{\mathrm{k}} \mathrm{kg}^{-1}\right)$} & 0.52 & 0.27 & 0.66 & 1.55 & 0.93 & 12.43 & Strong & Spherical \\
\hline & \multicolumn{8}{|c|}{$10-20 \mathrm{~cm}$} \\
\hline TOC $\left(g \cdot \mathrm{kg}^{-1}\right)$ & 0.44 & 0.19 & 0.56 & 1.65 & 0.99 & 28.04 & Moderate & Exponential \\
\hline $\operatorname{COp}\left(g \cdot \mathrm{kg}^{-1}\right)$ & 0.47 & 0.22 & 0.65 & 0.49 & 0.97 & 55.79 & Moderate & Gaussian \\
\hline \multirow[t]{2}{*}{ COam $\left(g \cdot \mathrm{kg}^{-1}\right)$} & 0.37 & 0.13 & 0.64 & 0.17 & 0.95 & 71.05 & Moderate & Exponential \\
\hline & \multicolumn{8}{|c|}{$20-40 \mathrm{~cm}$} \\
\hline TOC $\left(\mathrm{g} \cdot \mathrm{kg}^{-1}\right)$ & 0.38 & 0.14 & 0.53 & 0.98 & 0.99 & 37.57 & Moderate & Exponential \\
\hline $\operatorname{COp}\left(\mathrm{g} \cdot \mathrm{kg}^{-1}\right)$ & $0.5 \mathrm{I}$ & 0.26 & 0.55 & 0.34 & 0.94 & 20.58 & Strong & Exponential \\
\hline COam $\left(\mathrm{g}^{\circ} \mathrm{kg}^{-1}\right)$ & 0.63 & 0.40 & 0.66 & 0.95 & 1.01 & 6.29 & Strong & Exponential \\
\hline
\end{tabular}

(I)Total organic carbon; (2)Particulate organic carbon; (3)Organic carbon associated with minerals; (4)Organic carbon in fulvic acid fraction; (5)Organic carbon in humic acid fraction; (6)Humin fraction; (7)Correlation coefficient; (8)Determination coefficient; (9)Willmott's concordance index; (10)Standard error of the estimate; (II) Root-mean-square-error; (I2)Degree of spatial dependence; (13)Pure nugget effect.

Based on the models adjusted for each variable, it was possible to produce maps of the spatial distribution of the organic matter fractions (Figures I and 2), except for the variables that showed pure nugget effect (PNE).

With increasing depth, there was a decrease in TOC content (Figures IA and IB), COp (Figures IC and ID) and COam (Figures IE, IF, and IG). This pattern is due to the higher amount of organic matter present in superficial layers resulting from the deposition of plant residues and restoration of the root system.

Machado et al. (2014) evaluated changes in fertility and dynamics of SOM compartments of a RedYellow Latosol, under different systems of management of coffee plantations in an area under influence of the Atlantic Forest. The authors found higher TOC content at the depth of $0-5 \mathrm{~cm}\left(61.09 \mathrm{~g}^{\mathrm{kg}} \mathrm{kg}^{-1}\right)$ and lower content at $5-10 \mathrm{~cm}\left(38.36 \mathrm{~g} \cdot \mathrm{kg}^{-1}\right)$. These results are in agreement with the findings of the present study.

Higher values of COam (Figures IE, IF, and IG) than of COp were found (Figures IC and ID). The COam fraction, besides presenting a slower cycling, interacts more with the mineral fraction of the soil, which leads to greater accumulation (BAYER et al., 2004). Lower decomposition and a higher stabilization of $O M$ is favored owing to the fact that the study area does not undergo stirring (PAVINATO; ROSOLEM, 2008).

Guimarães et al. (20I2) characterized the physical fractions of SOM and determined the stocks of organic carbon and nitrogen in a Ultisol under a fragment of the Atlantic Forest, in Neópolis, Sergipe. They found COam content of 9.9 e $6.5 \mathrm{~g} \cdot \mathrm{kg}^{-1}$ at the depths of $0-10$ and 10 $30 \mathrm{~cm}$, respectively. The COp content in the same layers was 4.0 and $2.0 \mathrm{~g} \cdot \mathrm{kg}^{-1}$, respectively, in agreement with the results obtained in this study. The northern areas (Figure
I) had a higher content of physical fractions, likely owing to the higher disposal of vegetable and hyphal residues in this area (GOLCHIN et al., 1994).

The results found in this study are similar to those from previous studies demonstrating soil quality in the
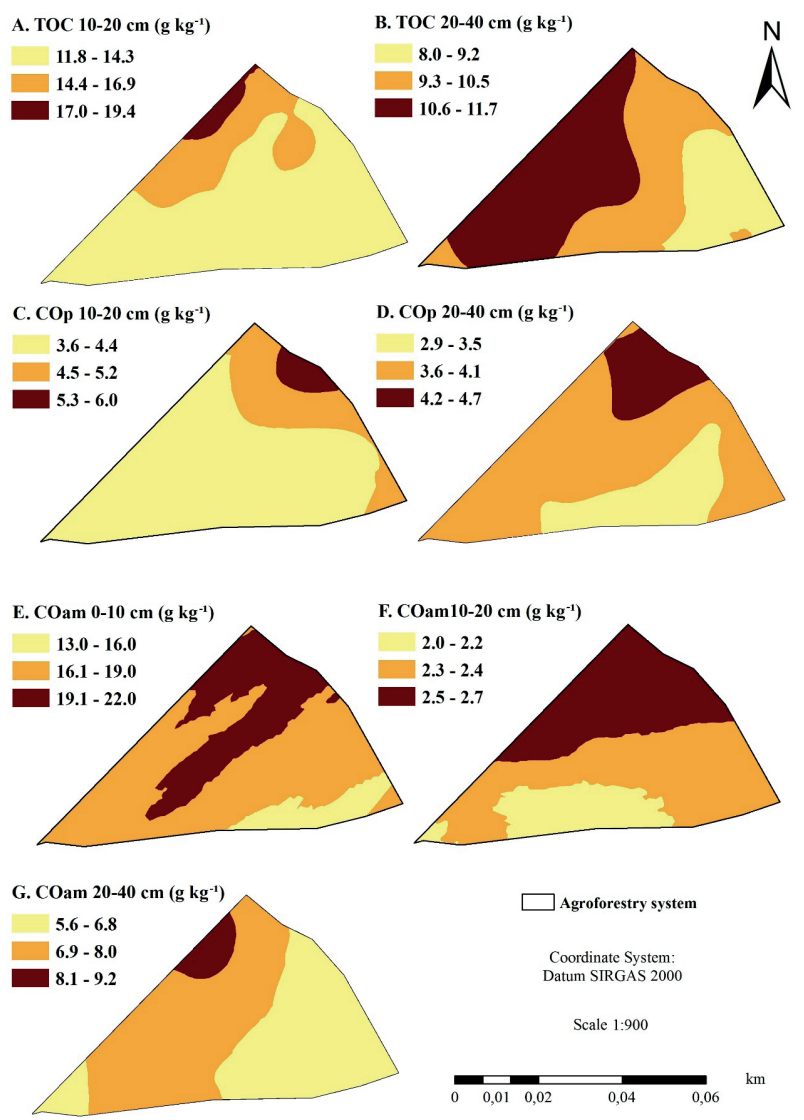

FIGURE I Spatial distribution maps of total organic carbon (TOC), particulate organic carbon (COp), and organic carbon associated with minerals (COam) at depths of $0-10,10-20$ and $20-40 \mathrm{~cm}$ in an AFS in the Atlantic Forest. 

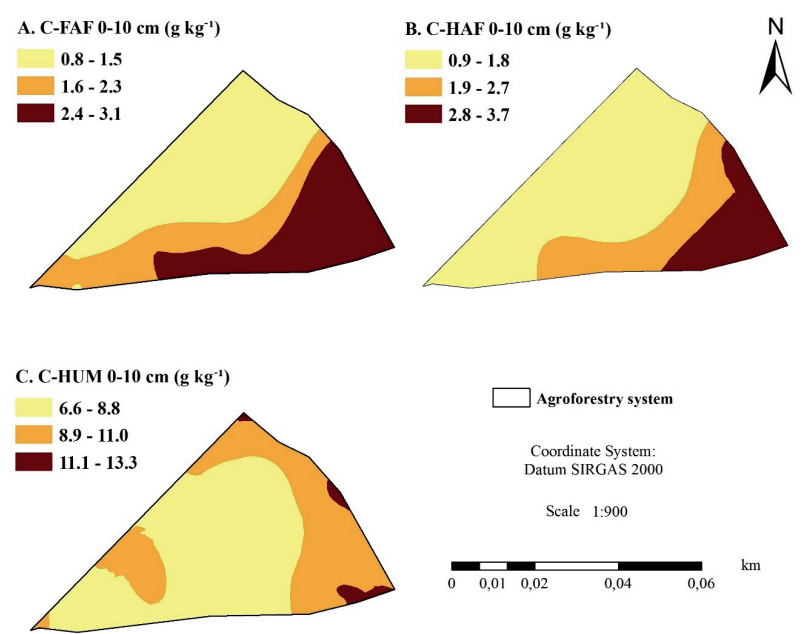

FIGURE 2 Spatial distribution maps of carbon in fulvic acid fraction (C-FAF), humic acid (C-HAF) and humin (C-HUM) at $0-10 \mathrm{~cm}$ depth, in an AFS in the Atlantic Forest.

AFS biome. Kunde et al. (2016) found, in naive forest from Southern Brazil, content of TOC, COp, and COam of $17.86,7.60$ and $10.26 \mathrm{~g} \mathrm{~kg}^{-1}$, respectively, at a depth of $0-5 \mathrm{~cm} ; 14.31,3.42$, and $10.89 \mathrm{~g} \cdot \mathrm{kg}^{-1}$, respectively, at a depth of $5-10 \mathrm{~cm} ; 22.85,3.94$, and $18.90 \mathrm{~g} \cdot \mathrm{kg}^{-1}$, respectively, at a depth of $10-20 \mathrm{~cm}$. Therefore, these results are nearly with those found in the agroforestry system in study.

Figure $2 \mathrm{C}$ shows higher carbon content in the $\mathrm{C}-\mathrm{HUM}$ fraction than in the other fractions (Figures $2 \mathrm{~A}$ and 2B). This result corroborates those from tropical climate studies, in which C-HUM is identified as the fraction with the greater carbon reserve in soils (EBELING et al., 20I I), and also indicates the presence of recalcitrant OM. This fraction is directly linked to the mineral part of the soil, while C-FAF and C-HAF are equivalent to OM from the labile forms (FONTANA et al., 20I I).

Carbon in C-FAF fraction (Figure $2 A$ ) is lower than in the C-HAF fraction (Figure 2B). According to Stevenson (1994), C-FAF has lower molecular weight, higher solubility and mobility in the soil, therefore rendering it more susceptible to leaching. In turn, C-HAF has higher molecular weight and aromatic carbon concentration, which makes this fraction more stable but also increases the time required for its formation. In order to improve the soil fertility, soil nutrient content and nutrient content, nitrogen, phosphorus and sulfur in the agroforestry system (PRIMO et al., 20I I), contribute to the increase of cation exchange capacity (CEC).

In the lower altitude of the AFS, in the eastern region, the highest carbon content in the C-FAF, C-HAF, and $\mathrm{C}-\mathrm{HUM}$ fractions was quantified. According to
Silva et al. (2007), when areas with lower slope have good drainage, the higher is the rate of deposition and the degree of humification of organic matter. SOM deposition also occurs in function of other factors, such as the arrangement and abundance of the species present in the area, of phenology, of the succession stage beside the edaphoclimatic factors (CALDEIRA et al., 2008).

Fontana et al. (2014) quantified the content of organic carbon and humic fractions of surface horizons of soil profiles in three topolithosequences, in Pinheiral, Rio de Janeiro, and verified that soils located in areas of flat relief, top, and floodplain presented a higher content of organic carbon and humic fractions. These results are in agreement with those of the present study.

The results from this study show that the values of the humic substances present in the AFS area are close to those observed in naive forests, such as in the study of Machado et al. (2014). They found content of C-FAF, C-HAF, and C-HUM of $6.84,8.99$, and $36.62 \mathrm{~g} \cdot \mathrm{kg}^{-1}$ at the $0-5 \mathrm{~cm}$ depth, respectively, and $5.5 \mathrm{I}, 7.42$, and $22.7 \mathrm{I}$ $\mathrm{g} \cdot \mathrm{kg}^{-1}$, respectively, at the $5-10 \mathrm{~cm}$ depth in a naive area of Atlantic forest, in Espírito Santo, Brazil. Fontana et al. (2010) evaluating the effect of different vegetation cover on the distribution of humic substances in the northern region of Rio de Janeiro, verified levels of C-FAF, C-HAF and C-HUM of $1.2,0.8$ and $3.7 \mathrm{~g} \cdot \mathrm{kg}^{-1}$ in the depth of $0-5$ $\mathrm{cm}$ and contents of $1.3,0.9$ and $1.9 \mathrm{~g} \cdot \mathrm{kg}^{-1}$, respectively, in the depth of $5-10 \mathrm{~cm}$ in a semi-deciduous forest. Miranda et al. (2007) evaluating the distribution of humic fractions and the chemical and spectroscopic characteristics of the humic acids extracted from the fragments of the Atlantic Forest and abandoned eucalyptus plantations in the state of Rio de Janeiro, observed mean levels of C-FAF, C-HAF and $\mathrm{C}-\mathrm{HUM}$ in the $0-10 \mathrm{~cm}$ depth of $1.9,1.1$ and $7.4 \mathrm{~g} \cdot \mathrm{kg}^{-1}$.

\section{CONCLUSION}

It was possible to spatialize the organic matter fractions of the soil, with the exceptions of TOC and COp variables at the $0-10 \mathrm{~cm}$ depth. Verification of soil quality in an agroforestry system through spatialization of organic matter fractions was efficient, and we found that the organic matter fraction content was comparable to that verified in soil under native forests.

\section{REFERENCES}

BAYER, C.; MARTIN-NETO, L.; MIELNICZUK, J.; PAVINATO, A. Armazenamento de carbono em frações lábeis da matéria orgânica de um Latossolo Vermelho sob plantio direto. Pesquisa Agropecuária Brasileira, v. 39, n. 7, p. 677-683, 2004. 
BENITES, V. M.; MADARI, B.; MACHADO, P. L. O. A. Extração e fracionamento quantitativo de substâncias húmicas do solo: um procedimento simplificado de baixo custo. Embrapa Solos, 2003. 7p. (Comunicado Técnico, 16)

CALDEIRA, M. V. W; VITORINO, M. D.; SCHAADT, S. S.; MORAES, E.; BALBINOT, R. Quantificação de serapilheira e de nutrientes em uma Floresta Ombrófila Densa. Semina: Ciências Agrárias, v. 29, n. I, p. 53-68, 2008.

CAMBARDELLA, C. A.; ELLIOT, E. T. Particulate soil organicmatter changes across a grassland cultivation sequence. Soil Science Society of American Journal, v. 56, p. 777783, 1992.

CAMBARDELLA, C. A.; MOORMAN, T. B.; NOVAK, J. M.; PARKIN, T. B.; KARLEN, D. L.; TURCO, R. F.; KONOPKA, A. E. Field scale variability of soil properties in central lowa soil. Soil Science Society of America Journal, v. 58, n. 5, p. I50I-I5II, 1994.

CHAER, G. M.; TÓTOLA, M. R. Impacto do manejo de resíduos orgânicos durante a reforma de plantios de eucalipto sobre indicadores de qualidade do solo. Revista Brasileira de Ciência do Solo, v. 31, p. I38I-1396, 2007.

DORAN, J. W.; PARKIN, T. B. Defining and assessing soil quality. In: DORAN, J. W.; COLEMAN, D. C.; BEZDICEK, D. F.; STEWART, B. A., eds. Defining soil quality for a sustainable environment. SSAA, 1994. p. I-20. (Special, 35)

EBELING, A. G.; ANJOS, L. H. C.; PEREIRA, M. G.; PINHEIRO, E. F. M.; VALLADARES, G. S. Substâncias húmicas e relação com atributos edáficos. Bragantia, v. 70, n. I, p. I57-165, 201 I.

FONTANA, A.; BRITO, R. J.; PEREIRA, M. G.; LOSS, A.; BENITES, V. M. Caracterização de substâncias húmicas da camada superficial do solo sob diferentes coberturas vegetais. Magistra, v. 22, n. I, p. 49-56, 2010.

FONTANA, A.; PEREIRA, M. G.; ANJOS, L. H. C.; SANTOS, A. C.; BERNINI, T. A. Matéria orgânica de horizontes superficiais em topolitossequências em ambiente de Mar de Morros, Pinheiral, RJ. Revista Ciência Agronômica, v. 45, n. 2, p. 22I-229, 2014.

FONTANA, A.; SILVA, C. F; PEREIRA, M. G.; LOSS, A.; BRITO, R. J.; BENITES, V. M. Avaliação dos compartimentos da matéria orgânica em área de Mata Atlântica. Acta Scientiarum. Agronomy, v. 33, n. 3, p. 545-550, 20 I I.

FROUFE, L. C. M.; RACHWAL, M. F. G.; SEOANE, C. E. S. Potencial de sistemas agroflorestais multiestrata para sequestro de carbono em áreas de ocorrência de Floresta Atlântica. Pesquisa Florestal Brasileira, v. 3I, n. 66, p. I43-I54, 201 I.

FROUFE, L. C. M.; SEOANE, C. E. S. Levantamento fitossociológico comparativo entre sistema agroflorestal multiestrato e capoeiras como ferramenta para a execução da reserva legal. Pesquisa Florestal Brasileira, v. 31, n. 67, p. 203-225, 2011.
GAZOLLA, P. R.; GUARESCHI, R. F.; PERIN, A.; PEREIRA, M. G.; ROSSI, C. Q. Frações da matéria orgânica do solo sob pastagem, sistema plantio direto e integração lavourapecuária. Ciências Agrárias, v. 36, n. 2, p. 693-704, 2015.

GOLCHIN, A.; OADES, J. M.; SKJEMSTAD, J. O.; CLARKE, P. Soil structure and carbon cycling. Australian Journal Soil Reserach, v. 32, n. 5, p. 1043-1068, 1994.

GUIMARÃES, D. V.; GONZAGA, M. I. S.; MELO-NETO, J. O.; REIS, A. F.; LIMA, T. S.; SANTANA, I. L. Qualidade da matéria orgânica do solo e estoques de carbono e nitrogênio em fragmento de Mata Atlântica do município de Neópolis, Sergipe. Scientia Plena, v. 8, n. 4, p. I-5, 2012.

ISAAKS, E. H.; SRIVASTAVA, R. M. An introduction to applied geoestatistics. Oxford University, 1989. $56 \mathrm{Ip}$.

JOSE, S. Agroforestry for ecosystem services and environmental benefits: an overview. Agroforestry Systems, v. 76, n. I, p. I-10, 2009.

KUNDE, R. J.; LIMA, C. L. R.; SILVA, S. D. A.; PILLON, C. N. Frações físicas da matéria orgânica em Latossolo cultivado com cana-de-açúcar no Rio Grande do Sul. Pesquisa Agropecuária Brasileira, v. 5I, n. 9, p. I520-I528, 2016.

LEITE, L. F. C.; FERREIRA, J. S.; VELOSO, M. E. C.; MOUSINHO, F. E. P.; ROCHA-JUNIOR, A. F. Variabilidade espacial das frações da matéria orgânica do solo em área degradada sob recuperação. Revista Brasileira de Engenharia Agrícola e Ambiental, v. 19, n. 4, p. 394-40I, 2015.

MACEDO, M. C. M. Integração lavoura e pecuária: o estado da arte e inovações tecnológicas. Revista Brasileira de Zootecnia, v. 38, p. I33-|46, 2009.

MACHADO, L. V.; RANGEL, O. J. P.; MENDONÇA, E. S.; MACHADO, R. V.; FERRARI, J. L. Fertilidade e compartimentos da matéria orgânica do solo sob diferentes sistemas de manejo. Coffee Science, v. 9, n. 3, p. 289-299, 2014.

MAGALHÃES, S. S. A.; WEBER, O. L. S.; SANTOS, C. H.; VALADÃO, F. C. A. Estoque de nutrientes sob diferentes sistemas de uso do solo de Colorado do Oeste - RO. Acta Amazonica, v. 43, n. I, p. 63-72, 2013.

MAIA, C. E. Qualidade ambiental em solo com diferentes ciclos de cultivo do meloeiro irrigado. Ciência Rural, v. 43, n. 4, p. 603-609, 2013.

MARCHETTI, A.; PICCINI, C.; R. FRANCAVIGLIA, R.; MABIT, L. Spatial distribution of soil organic matter using geostatistics: a key indicator to assess soil degradation status in central Italy. Pedosphere, v. 22, n. 2, p. 230-242, 2012.

MEISTER, K.; SALVIATI, V. O investimento privado e a restauração da Mata Atlântica no Brasil. Revista Intertox de Toxicologia, Risco Ambiental e Sociedade, v. 2, n. 2, p. 43-57, 2009. 
MIRANDA, C. C.; CANELLAS, L. P.; NASCIMENTO, M. T. Caracterização da matéria orgânica do solo em fragmentos de mata atlântica e em plantios abandonados de eucalipto. Revista Brasileira de Ciência do Solo, v. 31, p. 905-916, 2007.

MMA - Ministério do Meio Ambiente. Diretrizes para a política de conservação e desenvolvimento sustentável da Mata Atlântica. Brasília-DF, 1998. 26p.

NAIR, P. K. R. Agroforestry systems and environmental quality. Journal of Environmental Quality, v. 40, n. 3, p. 784$790,2011$.

PAVINATO, P. S.; ROSOLEM, C. A. Disponibilidade de nutrientes no solo - decomposição e liberação de compostos orgânicos de resíduos vegetais. Revista Brasileira de Ciência do Solo, v. 32, n. 91 I-920, 2008.

PEZARICO, C. R.; VITORINO, A. C. T.; MERCANTE, F. M.; DANIEL, O. Indicadores de qualidade do solo em sistemas agroflorestais. Revista de Ciências Agrárias, v. 56, n. I, p. $40-47,2013$.

PRIMO, D. C.; MENEZES, R. S. C.; SILVA, T. O. Substâncias húmicas da matéria orgânica do solo: uma revisão de técnicas analíticas e estudos no nordeste brasileiro. Scientia Plena, v. 7, n. 5, p. I-I3, $201 \mathrm{I}$.

ROSSI, C. Q.; PEREIRA, M. G.; GIACOMO, S. G.; BETTA, M.; POLIDORO, J. C. Frações húmicas da matéria orgânica do solo cultivado com soja sobre palhada de braquiária e sorgo. Bragantia, v. 70, n. 3, p. 622-630, 201 I.

SANTOS, D. C.; FARIAS, M. O.; LIMA, C. L. R.; KUNDE, R. J.; PILLON, C. N.; FLORES, C. A. Fracionamento químico e físico da matéria orgânica de um Argissolo Vermelho sob diferentes sistemas de uso. Ciência Rural, v. 43, n. 5, p. 838-844, 2013.

SANTOS, H. G.; JACOMINE, P. K. T.; ANJOS, L. H. C.; OLIVEIRA, V. A.; LUMBRERAS, J. F.; COELHO, M. R.; ALMEIDA, J. A.; CUNHA, T. J. F.; OLIVEIRA, J. B. Sistema Brasileiro de Classificação de Solos. Embrapa, 2013. 353p.
SILVA, A. C.; TORRADO, P. V.; PÉREZ, M. G; MARTIN-NETO, L.; VASQUEZ, F. M. Relações entre matéria orgânica do solo e declividade de vertentes em toposequência de Latossolos do Sul de Minas Gerais. Revista Brasileira de Ciência do Solo, v. 31, n. 5, p. I059-1068, 2007.

SILVA, C. S.; PEREIRA, M. G.; DELGADO, R. C.; SILVA, E. V. Spatialization of soil chemical and physical attributes in an agroforestry system, Seropédica, Brazil. Cerne, v. 22, n. 4, p. $407-414,2016$.

SOUZA, Z. M.; MARQUES-JÚNIOR, J.; PEREIRA, G. T. Variabilidade espacial da estabilidade de agregados e matéria orgânica em solos de relevos diferentes. Pesquisa Agropecuária Brasileira, v. 39, n. 5, p. 49|-499, 2004.

STEVENSON, F. J. Humus chemistry: genesis, composition, reactions. 2.ed. J. Wiley, 1994. 496p.

SWIFT, R. S. Organic matter characterization. In: SPARKS, D. L. (Ed). Methods of soil analysis. America Society of Agronomy, 1996. p. I0II-1020.

WARRICK, A.W.; NIELSEN, D.R. Spatial variability of soil physical properties in the field. In: HILLEL, D. (Ed.) Applications of soil physics. Academic press, 1980. p. 319-344.

WILLMOTT, C. J. Some comments on the evaluation of model performance. BulletinAmerican Meteorological Society, v.63, p.1309-1313, 1982.

YAMAMOTO, J. K.; LANDIM, P. M. B. Geoestatística: conceitos e aplicações. Oficina de Textos, 2013. 215p.

YEOMANS, J.C.; BREMNER, J.M. A rapid and precise method for routine determination of organic carbon in soil. Soil Science and Plant Analysis, v. 19, p. 1467-1476, 1988.

ZONTA, J. H.; BRANDÃO, Z. N.; MEDEIROS, J. C.; SANA, R. S.; SOFIATTI, V. Variabilidade espacial da fertilidade do solo em área cultivada com algodoeiro no Cerrado do Brasil. Revista Brasileira de Engenharia Agrícola e Ambiental, v. 18, n. 6, p. 595-602, 2014. 